\title{
Nazivlje u Markovićevoj Etici
}

Bojan Marotti*

bojan.marotti@zg.t-com.hr https://doi.org/10.31192/np.16.3.5

UDK: 1Marković, F.

811.163.42'373.46:1

Izvorni znanstveni rad / Original scientific paper

Primljeno: 8. kolovoza 2018.

Prihvaćeno: 22. rujna 2018.

Hrvatski filozof $i$ književnik Franjo pl. Marković u svome je filozofiranju veliku pozornost posvećivao nazivlju, $i$ to kako nazivlju općenito, tako posebice filozofskomu nazivlju. Ta se njegova skrb za nazivlje u ovome članku pokazuje na primjeru Etike. Iz toga je spisa odabrano dvjesto riječi, od kojih se većina može smatrati filozofskim ili, u šrem smislu, znanstvenim nazivcima, ali ima medu njima i takvih koje pripadaju u opći jezik. Da bi se provjerilo koliko je od tih riječi potvrđeno u hrvatskome jeziku, odabrano je šest hrvatskih rječnika, $i$ to: Parčićev Vocabolario croato-italiano (1901.), Akademijin rječnik (1880.-1976.), Broz-Ivekovićev Rječnik hrvatskoga jezika (1901.), Šonjin Rječnik hrvatskoga jezika (2000.), Anićev Veliki rječnik hrvatskoga jezika (2004.) i Veliki rječnik hrvatskoga standardnog jezika glavne urednice Ljiljane Jojić (2015.). Potom je provedena usporedba i izvršena potanka raščlamba. Zaključak je da najviše navedenih Markovićevih riječi postoji u Akademijinu i u Parčićevu rječniku, nešto manje od $55 \%$, dočim preostala četiri rječnika imaju ili malo manje od $20 \%$ (Broz-Iveković, Šonje i Anić) ili malo više od 20 \% (Jojić). Ti podatci istodobno pokazuju i Markovićevu skrb za (filozofsko) nazivlje, ali ujedno i stanje u kojem se danas nalazi hrvatski (književni) jezik, što posebice vrijedi za rječnike »suvremenoga jezika, gdje se može potvrditi jedva dvadesetak posto navedenih riječi. A valja biti svjestan da bi taj postotak zacijelo bio još porazniji da se sličnoj razglobi podvrgne golema Markovićeva Logika. Na kraju se predlaže da se kritički objavi cjelokupna Markovićeva ostavština, i to ne samo zato da bi Markovićeva misao bila dostupna, nego i zato da se omogući uvid u silno bogatstvo filozofskoga nazivlja koje nam u svojim djelima nudi Franjo pl. Marković.

Ključne riječi: Franjo pl. Marković, etika, (filozofsko) nazivlje, hrvatski rječnici, povijest hrvatskoga jezika, hrvatski književni jezik.

\footnotetext{
* Dr. sc. Bojan Marotti, Zavod za povijest i filozofiju znanosti, Hrvatska akademija znanosti i umjetnosti; Ante Kovačića 5, HR-10000 Zagreb.
} 
I upravo ovo je znamen $i$ vriednost našega nastojanja oko znanosti na našem narodnom jeziku, da nam je tim dozvoljen $i$ baš otvoren potrebni svesvjetski vidokrug [...].

Franjo pl. Marković

\section{Uvod}

U dvama arhivima Hrvatske akademije znanosti i umjetnosti - $\mathrm{u}$ (glavnome) Arhivu HAZU te u Arhivu Odsjeka za povijest hrvatske književnosti Zavoda za povijest hrvatske književnosti, kazališta i glazbe HAZU - čuva se bogata ostavština hrvatskoga filozofa, klasičnoga filologa, književnika, kazališnoga i književnoga kritičara Franje pl. Markovića (1845.-1914.), prvoga profesora filozofije na obnovljenome Zagrebačkome sveučilištu (1874.). U filozofskome se dijelu te ostavštine najvećim dijelom nalaze Markovićeva predavanja, ili pak pripreme za predavanja, i to različitoga stupnja dovršenosti. Marković je na Sveučilištu predavao sve do odlaska u mirovinu (1909.), a povremeno i poslije - gotovo do smrti. Primjerice, još je u lipnju 1914. imao predavanja iz etike, a umro je 15. rujna iste godine.

Marković je predavao gotovo sve filozofske struke, od logike do estetike, pa i neke znanosti koje danas ne smatramo dijelovima filozofije, primjerice psihologiju i pedagogiju. Budući pak da se je za svoja predavanja pismeno pripremao, tj. ili ih je $u$ potpunosti unaprijed sastavljao, ili ih je djelomično zapisivao $u$ obliku opsežnih bilježaka, posve je razumljivo da je broj spomenutih rukopisa neobično velik. K tomu, Marković je pojedine predmete predavao dugi niz godina, dakle »ciklički«, pa je svoja predavanja postupno nadopunjavao, tako da su ona s vremenom postajala dvostruko, pa i trostruko veća negoli što su bila u trenutku kada je taj predmet započeo predavati. Neka je od tih predavanja naknadno redigirao i očevidno pripremao za objavljivanje. ${ }^{1}$ Tako je, primjerice, bilo s predavanjima iz estetike, koja je pod naslovom Razvoj i sustav obćenite estetike sam objavio godine $1903 .^{2}$ Na žalost, od onih rukopisa koji se čuvaju u Arhivu HAZU, do danas je objavljeno vrlo malo. Od neobjavljenih treba svakako spomenuti za objavljivanje priređene rukopise Uvoda u filozofiju (više od 450 stranica), Nauke o spoznaji (više od 150 stranica) i Povijesti filozofije (gdje pojedini dijelovi nisu posve uređeni, ali primjerice rasprava o Leibnizu obaseže više od 100 stranica), potom predavanja iz psihologije (nešto manje od 650

\footnotetext{
${ }^{1}$ Vidi o tome potanje u mome članku: Bojan MAROTTI, O Markovićevim filozofskim rukopisima u arhivima HAZU, Civitas Crisiensis, 2 (2016), 109-152, posebice 115-119, tj. poglavlje Markovićeva rukopisna ostavština, odakle prenosim podatke.

2 Vidi Franjo MARKOVIĆ, Razvoj i sustav obćenite estetike, Zagreb, Nakladom kr. hrv.-slav.dalm. zemaljske vlade, 1903. (pretisak: Split, Izdavačka radna organizacija LOGOS, 1981.).
} 
stranica) i pedagogije (oko 500 stranica), ${ }^{3}$ te napokon predavanja iz Logike, koja su ujedno i najopsežnija. ${ }^{4}$

Od filozofskih pak rukopisa koji se čuvaju u Arhivu Odsjeka za povijest hrvatske književnosti Zavoda za povijest hrvatske književnosti, kazališta i glazbe HAZU, dosad je objelodanjena samo Etika. ${ }^{5} \mathrm{O}$ rukopisu Etike, kao i o ustroju toga spisa, potanko sam pisao u pogovoru navedenoga izdanja, ${ }^{6}$ pa bih ovdje ponovio samo osnovno. Ponajprije, taj rukopis nažalost nije očuvan u cjelini. Posrijedi je litografirani primjerak početnoga dijela Etike, pisan (vrlo čitljivo) različitim rukama na papiru veličine (približno) $26,5 \mathrm{~cm}$ x $21 \mathrm{~cm}$, koji ima 150 stranica, a u kojem se nalaze Uvod u etiku i dio Sustava etike. Bit će da je primjerak nastao prijepisom s autografa, no naknadno je u nj unesen velik broj ispravaka, zacijelo Markovićevom rukom. Tomu valja pridodati i jedan izdvojeni list papira veličine (približno) $24,5 \mathrm{~cm}$ x $21 \mathrm{~cm}$, ispisan obostrano, koji se svojim obrojem nastavlja na spomenuti litografirani primjerak, te je na dvjema njegovim stranama zapisano 151 i 152 . Taj je list papira međutim autograf, tj. pisan je Markovićevom rukom. I to je ono što je u izdanju objelodanjeno i ujedno kritički priređeno.

U nas postoji neka vrsta »uvjerenja«, da ne kažem »predrasude«, da je Marković (prije svega) estetičar (što dakako ne stoji). Najbolji međutim način da se spomenuta »predrasuda « ukloni jest taj da se Markovićevi rukopisi objave. Svi, ili makar velika većina. Jer tada bi napokon njegova misao mogla biti proučena u svojoj cjelovitosti.

\section{Markovićeva skrb za nazivlje}

Poznato je da je Franjo pl. Marković u svome filozofiranju veliku pozornost posvećivao nazivlju, i to kako nazivlju općenito, tako posebice filozofskomu

${ }^{3}$ Iz posebnoga Markovićeva rukopisa Uvod u pedagogiku objavljena su dosad dva ulomka. Priredio ih je Ivan ČEHOK, i to: Uvod u pedagogiku, u: Franjo ZENKO, Novija hrvatska filozofija, Zagreb, Školska knjiga, 1995, 115-121 (Hrestomatija filozofije, sv. 10), te Sustav općenite pedagogike, u: Zenko, Novija hrvatska filozofija..., 122-128. Objavljen je i rukopis pod naslovom Posebna gimnazijska pedagogika, a priredio ga je Ante BEŽEN, i to kao: Gimnazijska pedagogika Franje Markovića (prvotisak prema izvornom rukopisu), Napredak, 149 (2008) 3, 351-368.

${ }^{4}$ Iz Markovićeve su rukopisne Logike dosad objavljena četiri ulomka. Dva je priredio Srećko KOVAČ, i to: Logika, Prilozi za istraživanje hrvatske filozofske baštine, 18 (1992) 35-36, 247258, te Vrsti sudova po njihovih oblicih, Prilozi za istraživanje hrvatske filozofske baštine, 19 (1993) 37-38, 251-265. Preostala sam dva priredio kao posebne priloge uz dva svoja članka, i to: Psihologijska podloga logici, u: Stipe KUTLEŠA (prir.), Filozofijsko djelo Franje pl. Markovića, Zagreb, Matica hrvatska, 2016, 101-130, te O riečih, Civitas Crisiensis, 2 (2016), 125-147.

${ }^{5}$ Vidi Franjo MARKOVIĆ, Etika, kritičko izdanje priredio i pogovor napisao Bojan Marotti, Zagreb, Matica hrvatska, 2016.

${ }^{6}$ Vidi Bojan MAROTTI, Franjo pl. Marković, u: Marković, Etika..., 199-241; usp. i prikaz navedene knjige: Bojan MAROTTI, Marković nije bio samo estetičar, Nova prisutnost, 15 (2017) 2, 300-309. 
nazivlju. ${ }^{7}$ Nažalost, velik dio njegovih nazivaka sve do danas nije postao sastavnim dijelom hrvatske filozofije. Markovićev odnos prema nazivlju, upravo njegova skrb za nazivlje, jasno se vidi u svakome njegovu spisu. Ovdje bih tu njegovu skrb pokazao na primjeru Etike. U tu sam svrhu odabrao dvije stotine riječi iz toga spisa, od kojih se većina može smatrati filozofskim ili, u širem smislu, znanstvenim nazivcima, ali ima među njima i takvih koje pripadaju u opći jezik. Evo tih dvjesto primjera (ne tumačim pri tome značenje; ono što se nalazi u zagradi navodi sam Marković):

\begin{tabular}{ll} 
bezosjetben & izkvara \\
bezosjetbenost & izmir \\
bezosjetovan & izmirba \\
bićan & iznebiti \\
biće (substancija) & izvršba \\
bićnost & izvrština \\
bistvo & jav \\
bivstvo & ječan \\
blagohlepac & jednobitan \\
blagohotan & jednosljedan (consequentan) \\
blagota (sreća) & kakvotan \\
bližika (svojta) & kolikotan \\
boljak & krivorota \\
činba & krivosudje (praejudicia) \\
činitba & ljepoćuće \\
čuvstvo & ljepoćutan \\
ćućenje & medjusobica (relacija) \\
ćutnja & miloćuće \\
dobrohotan & mišljevina \\
dobrohotnik & mrzotan \\
dobrohotnost & munjina \\
dopunak & nasporivanje \\
doumak & naumice \\
doznaja & nebićan \\
družljivost & nenauman \\
dvobir & nenaumice \\
dvobirak (alternativa) & nepredobitan \\
goj & nevrstnik \\
hoćenje & obastanak \\
hotnja & obićen \\
izbir (selekcija) & obret \\
izjav & obsežnost (extensivnost) \\
\hline
\end{tabular}

\footnotetext{
${ }^{7}$ Usp. i Marotti, Franjo pl. Marković, u: Marković, Etika..., 204-205.
} 


\begin{tabular}{ll} 
obstanak & preoblika \\
obziričan (relativan) & prepuštaj \\
oćut & presilje \\
odlučnost (intenzivnost) & pretega \\
odmjera & prietvorba \\
odredba (definicija) & prikor \\
odsjajivalo & prikornost \\
ograničba & prirok \\
omjerje & prisilje \\
opravljati & prisudba \\
osebitost & pritruha \\
osjećalo & prividjaj \\
osjetben & priznaja \\
osjetbenost & razbirak \\
osjetovan & razglabanje \\
osobnički (subjektivni) & razmišljaj \\
ostan & razredba \\
označba & razumnik \\
palik & razvid \\
podmet & razvrstba \\
podredjenost (inferiornost) & riek (terminus) \\
pogodljivost & samodružan (relativan) \\
pohtievati & samoseban (apsolutan) \\
pohtjeti & samosilnik \\
pojasnitba & samosvojan (autonoman) \\
pokraćenica & samotvoran \\
pokretalica & samovladalac \\
pomišljaj & samoživstvo (egoizam) \\
pomjestan & sasobica \\
poreznik & sastavina \\
porječnost & sgodjaj \\
porjeka & složaj \\
posljedak & sljednji \\
postupica (gradacija) & snemiliti se \\
posvojitba & sobstvo \\
povodjaj & spojevina \\
pozbiljen & sporazumak \\
pra & sporazumnik \\
pravoslovlje & stanovit \\
predsuda & sućutje \\
pregledba & sućutnik \\
preobličba & supor \\
\hline &
\end{tabular}




suprotak
suprotivština
suprotnik
suvrst
svebiće
svjestit
svojiti
svojtljivost
svrhunaravan
šara
tjelesnoćutan
trenovan
tvor
tvorilo
učin
udobravanje
udružba
ujedinitba
ujedinjenost (koncentracija)
umjera (ekvilibrij)
umotvor
umotvorina
umstveni
upravljalo
usilan
usiljenost

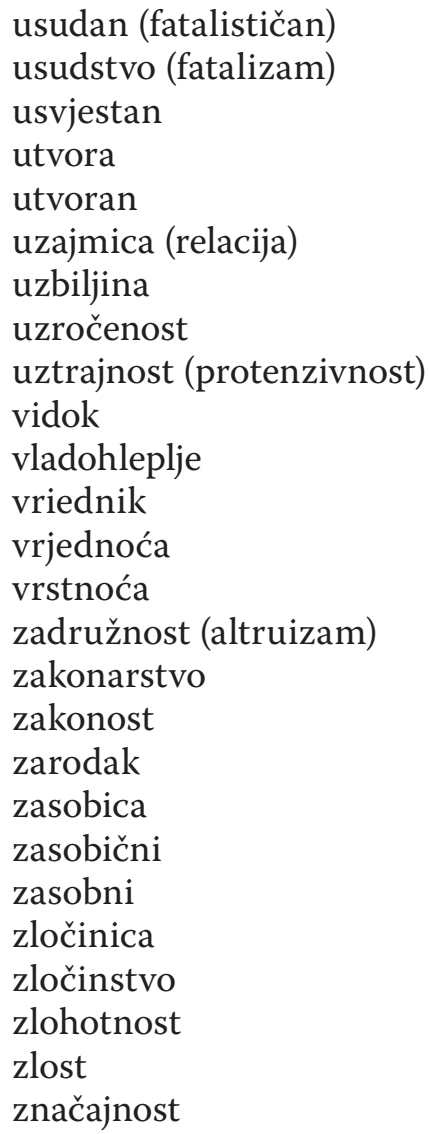

Da bi se provjerilo koliko je tih riječi potvrđeno u hrvatskome jeziku, odabrao sam šest hrvatskih rječnika. Kažem »potvrđeno«, dakle ne koliko ih je doista zaživjelo, jer za to bi bila potrebna raščlamba svih filozofskih djela pisanih hrvatski, nego koliko je od tih riječi, recimo, »zapisano«. Evo koje sam hrvatske rječnike uzeo u obzir (u uglatim zagradama navodim pokratu):

- Dragutin PARČIĆ, Vocabolario croato-italiano, terza edizione corretta ed aumentata, Zara, Tipografia editrice »Narodni List «, 1901. (pretisak: Zagreb, ArTresor studio, 1995.) [PARČIĆ]

- Rječnik hrvatskoga ili srpskoga jezika, na svijet izdaje Jugoslavenska akademija znanosti i umjetnosti, sv. I-XXIII, Zagreb, Jugoslavenska akademija znanosti i umjetnosti, 1880.-1976. [ARj]

· Ivan BROZ, Franjo IVEKOVIĆ, Rječnik hrvatskoga jezika, sv. I-II, Zagreb, Štamparija Karla Albrechta (Jos. Wittasek), 1901. [BI]

- Jure ŠONJE (gl. ur.), Rječnik hrvatskoga jezika, Zagreb, Leksikografski zavod Miroslav Krleža i Školska knjiga, 2000. [Š] 
- Vladimir ANIĆ, Veliki rječnik hrvatskoga jezika, priredila Ljiljana Jojić, Zagreb, Novi Liber, 2004. [A]

- Ljiljana JOJIĆ (gl. ur.), Veliki rječnik hrvatskoga standardnog jezika, Zagreb, Školska knjiga, 2015. [J]

Budući da je Parčićev rječnik hrvatsko-talijanski, tj. jedini hrvatsko-inojezični rječnik od šest odabranih, u preglednici navodim i talijanske otpovjednice. Pri tome ne donosim sva značenja koja ima Parčić, nego samo ona koja su filozofski »zanimljiva« (ili »najzanimljivija«). Primjerice, za riječ biće Parčić navodi ove talijanske otpovjednice: ${ }^{8}$ »1) ente; 2) essenza; 3) esistenza; 4) condizione di vita; 5) facoltà o averi, sostanze (in beni stabili)." Od tih sam značenja uzeo ova tri: ente, essenza i esistenza. K tomu, kada se jedna riječ upućuje na drugu, navodim značenja te druge riječi. Tako Parčić riječ jednobitan (kao i jedinobićan i jednobistven) upućuje na jedinosućan, što pak na talijanski prevodi kao consustanziale. ${ }^{9}$ Stoga i ja uz jednobitan donosim consustanziale. Što se ostalih rječnika tiče, bilježim samo imaju li dotičnu riječ ili ju nemaju (znakovima $+\mathrm{i}-)$.

Parčićev Rječnik hrvatsko-talijanski i Broz-Ivekovićev Rječnik hrvatskoga je$z i k a$ objelodanjeni su iste godine, $\mathrm{tj}$. 1901. Pripadaju međutim posve različitim jezikoslovnim školama, pa im se utoliko i pristupi hrvatskomu (književnomu) jeziku uvelike razlikuju. Štoviše, upravo je ta godina, na neki način i prekretnica u novijoj povijesti hrvatskoga (književnoga) jezika. I doista, "posustajanje« Zagrebačke filološke škole, jasno vidljivo nakon Veberove smrti godine 1889., te posebice tijekom devedesetih godina devetnaestoga stoljeća, kao da dospijeva do svoga vrhunca, ili svoga veličanstvenoga »kraja«, velebnim Parčićevim objavkom, jednim od zacijelo najboljih hrvatskih rječnika. S druge pak strane, Broz-Ivekovićev rječnik, ili kako ga katkada zovu - "prošireni Vuk«, ${ }^{10}$ uz Brozov pravopis (1892. ${ }^{11}$ i Maretićevu slovnicu (1899.), ${ }^{12}$ označuje ono što se u našem jezikoslovlju voli nazivati »pobjedom hrvatskih vukovaca«. A i Akademijin rječnik pripada velikim dijelom toj istoj školi, jer je, posebice u svojim početcima, kada ga je obrađivao Đuro Daničić, bio izrazito nesklon Zagrebačkoj školi.

Što se pak tiče triju preostalih rječnika, sve su to rječnici suvremenoga hrvatskoga književnoga (ili »standardnoga«) jezika, a objelodanjeni su u razmaku

\footnotetext{
${ }^{8}$ Vidi Parčić, Vocabolario croato-italiano..., 22.

${ }_{9}$ Isto, 303-304.

${ }^{10}$ Misli se na drugo izdanje Vukova rječnika od godine 1852. Vidi Vuk Stefanović KARADŽIĆ, Srpski rječnik istumačen njemačkijem i latinskijem riječima, Beč, Štamparija jermenskoga namastira [tako!], 1852. (zapravo: Вук Стефановић Караџић, Сриски рјечник истумачен њемачкијем и латинскијем ријечима, Беч, Штампарија јерменскога намастира, 1852.).

${ }^{11}$ Vidi Ivan BROZ, Hrvatski pravopis, Zagreb, Troškom i nakladom kr. hrv.-slav.-dalm. zemaljske vlade, 1892.

${ }^{12}$ Vidi Tomo MARETIĆ, Gramatika i stilistika hrvatskoga ili srpskoga književnog jezika, Zagreb, Štampa i naklada knjižare L. Hartmana (Kugli i Deutsch), 1899.
} 
od petnaest godina. Posljednji, Veliki rječnik hrvatskoga standardnog jezika, ujedno je i najveći od njih. Ali evo kako izgleda preglednica:

\begin{tabular}{|c|c|c|c|c|c|c|}
\hline MARKOVIĆ & PARČIĆ & $\mathbf{A R j}$ & BI & $\check{\mathbf{S}}$ & A & $\mathbf{J}$ \\
\hline bezosjetben & - & - & - & - & - & - \\
\hline bezosjetbenost & - & - & - & - & - & - \\
\hline bezosjetovan & - & - & - & - & - & - \\
\hline bićan & - & - & - & - & - & - \\
\hline biće & ente; essenza; esistenza & + & + & + & + & + \\
\hline bićnost & - & - & - & - & - & - \\
\hline bistvo & essenza; sostanza & + & - & - & - & + \\
\hline bivstvo & essenza; sostanza & + & - & + & + & + \\
\hline blagohlepac & - & - & - & - & - & - \\
\hline blagohotan & - & + & - & - & + & + \\
\hline blagota & - & + & + & - & - & - \\
\hline bližika & un vicino, stretto parente & + & + & - & - & - \\
\hline boljak & miglioria & - & - & - & - & - \\
\hline činba & azione & + & - & - & + & + \\
\hline činitba & effettuazione & - & - & + & + & + \\
\hline čuvstvo & senso; sentimento & + & + & + & + & + \\
\hline ćućenje & sentimento; senso & + & + & - & + & - \\
\hline ćutnja & sentore & + & - & + & - & + \\
\hline dobrohotan & benevolo & + & - & + & + & + \\
\hline dobrohotnik & - & + & - & - & - & - \\
\hline dobrohotnost & benevolenza & + & - & + & + & + \\
\hline dopunak & completamento, supplemento & - & - & - & - & - \\
\hline doumak & argomentazione; sillogismo & - & - & - & - & - \\
\hline doznaja & - & - & - & - & - & - \\
\hline družljivost & socievolezza, affabilità & - & - & - & - & - \\
\hline dvobir & alternativa, scelta tra due oggetti & - & - & - & - & - \\
\hline dvobirak & - & - & - & - & - & - \\
\hline goj & tranquillità; educazione & + & + & - & - & - \\
\hline hoćenje & il volere; volontà & + & + & - & - & - \\
\hline hotnja & - & + & - & - & - & - \\
\hline izbir & - & - & - & - & - & - \\
\hline izjav & - & - & - & - & - & - \\
\hline izkvara & - & - & - & - & - & - \\
\hline izmir & - & - & - & - & - & - \\
\hline izmirba & - & - & - & - & + & + \\
\hline iznebiti & sconciare ili parto, abortire & + & + & - & - & - \\
\hline izvršba & effettuazione; esecuzione & + & - & - & - & - \\
\hline izvrština & pregio, eccellenza & + & + & - & - & - \\
\hline jav & risposta alla chiamata; voce & + & + & - & - & - \\
\hline
\end{tabular}




\begin{tabular}{|c|c|c|c|c|c|c|}
\hline ječan & affermativo; positivo & + & - & - & - & - \\
\hline jednobitan & consustanziale & + & - & - & - & - \\
\hline jednosljedan & - & - & - & - & - & - \\
\hline kakvotan & - & - & - & - & - & - \\
\hline kolikotan & - & - & - & - & - & - \\
\hline krivorota & falso giuramento, spergiuro & + & - & - & - & - \\
\hline krivosudje & - & + & - & - & - & - \\
\hline ljepoćuće & - & - & - & - & - & - \\
\hline ljepoćutan & - & - & - & - & - & - \\
\hline medjusobica & - & - & - & - & + & + \\
\hline miloćuće & - & - & - & - & - & - \\
\hline mišljevina & - & - & - & - & - & - \\
\hline mrzotan & - & + & - & - & - & - \\
\hline munjina & elettricità & + & - & - & + & + \\
\hline nasporivanje & - & - & - & - & - & - \\
\hline naumice & bella posta, di proposito & - & - & - & - & - \\
\hline nebićan & - & - & - & - & - & - \\
\hline nenauman & - & - & - & - & - & - \\
\hline nenaumice & - & - & - & - & - & - \\
\hline nepredobitan & invincibile & + & - & - & - & - \\
\hline nevrstnik & - & - & - & - & - & - \\
\hline obastanak & - & - & - & - & - & - \\
\hline obićen & - & - & - & - & - & - \\
\hline obret & la (cosa) scoperta, invenzione & - & - & - & - & - \\
\hline obsežnost & estensione & + & - & + & + & + \\
\hline obstanak & durata; sussistenza, esistenza & + & - & + & + & + \\
\hline obziričan & - & - & - & - & - & - \\
\hline oćut & - & + & - & - & - & + \\
\hline odlučnost & determinatezza, risolutezza & + & - & + & - & + \\
\hline odmjera & commisurazione, determinazione & + & - & - & - & - \\
\hline odredba & ordinamento; determinazione & + & + & + & + & + \\
\hline odsjajivalo & - & + & - & - & - & - \\
\hline ograničba & - & - & - & - & - & - \\
\hline omjerje & - & - & - & - & - & - \\
\hline opravljati & sbrigare; amministrare & + & + & + & - & + \\
\hline osebitost & particolarità & - & - & - & - & - \\
\hline osjećalo & senso, organo di sensibilità & + & - & - & - & - \\
\hline osjetben & - & - & - & - & - & - \\
\hline osjetbenost & - & - & - & - & - & - \\
\hline osjetovan & - & - & - & - & - & - \\
\hline osobnički & - & - & - & - & - & - \\
\hline ostan & pungolo, stimolo & + & + & + & - & - \\
\hline označba & contrassegno; definizione & - & - & - & - & - \\
\hline palik & imitazione, contraffazione & + & + & - & - & - \\
\hline
\end{tabular}




\begin{tabular}{|c|c|c|c|c|c|c|}
\hline podmet & oggetto sottoposto; soggetto & + & + & + & + & + \\
\hline podredjenost & dipendenza (quale subalterno) & + & - & + & + & + \\
\hline pogodljivost & agevolezza & + & - & - & - & - \\
\hline pohtievati & - & - & - & - & - & - \\
\hline pohtjeti & - & - & - & - & - & - \\
\hline pojasnitba & - & - & - & - & - & - \\
\hline pokraćenica & - & - & - & - & - & - \\
\hline pokretalica & - & - & - & - & - & - \\
\hline pomišljaj & pensiero, idea & + & + & + & + & + \\
\hline pomjestan & locale & + & + & - & - & - \\
\hline poreznik & collettore; contribuente & + & - & + & + & + \\
\hline porječnost & - & - & - & - & - & - \\
\hline porjeka & - & - & - & - & - & - \\
\hline posljedak & conseguenza; esito, risultato & + & + & + & + & + \\
\hline postupica & progressione & + & - & - & - & - \\
\hline posvojitba & - & - & - & - & - & - \\
\hline povodjaj & - & + & - & - & - & - \\
\hline pozbiljen & - & - & - & - & - & - \\
\hline pra & causa contenziosa, lite & + & - & - & - & - \\
\hline pravoslovlje & scienza di diritto, giurisprudenza & + & - & - & - & - \\
\hline predsuda & pregiudizio, opinione preconcetta & + & - & - & - & - \\
\hline pregledba & revisione, ispezione & + & - & - & - & - \\
\hline preobličba & - & - & - & - & - & - \\
\hline preoblika & - & - & - & + & + & + \\
\hline prepuštaj & - & - & - & - & - & - \\
\hline presilje & baldanza, soperchieria & - & - & - & - & - \\
\hline pretega & preponderanza, prevalenza & + & + & + & + & + \\
\hline prietvorba & - & - & - & - & - & - \\
\hline prikor & rimprovero; onta, vituperio & + & - & - & - & - \\
\hline prikornost & - & - & - & - & - & - \\
\hline prirok & predicato & + & + & + & + & + \\
\hline prisilje & costringimento, coazione & - & - & - & - & - \\
\hline prisudba & - & - & - & - & - & - \\
\hline pritruha & piccola magagna, imperfezione & + & - & - & - & - \\
\hline prividjaj & - & - & - & - & - & - \\
\hline priznaja & ricognizione & + & - & - & - & - \\
\hline razbirak & - & - & - & - & - & - \\
\hline razglabanje & - & + & + & + & - & + \\
\hline razmišljaj & - & + & - & - & - & - \\
\hline razredba & ripartimento; classificazione & + & + & + & - & + \\
\hline razumnik & un assennato, intelligente & + & - & - & - & + \\
\hline razvid & disamina; verificazione & - & - & - & - & - \\
\hline razvrstba & - & + & - & - & - & - \\
\hline riek & frase; periodo; sentenza & + & + & + & + & - \\
\hline
\end{tabular}




\begin{tabular}{|c|c|c|c|c|c|c|}
\hline samodružan & - & - & - & - & - & - \\
\hline samoseban & considerato in sè & + & - & - & - & - \\
\hline samosilnik & tiranno, despota & + & - & - & - & - \\
\hline samosvojan & $\begin{array}{l}\text { privato, personale; } \\
\text { indipendente }\end{array}$ & + & - & + & + & + \\
\hline samotvoran & $\begin{array}{c}\text { semplice, naturale; fatto d' un sol } \\
\text { pezzo }\end{array}$ & + & + & - & - & + \\
\hline samovladalac & monarca & + & - & - & - & - \\
\hline samoživstvo & vita solitaria, da misantropo & + & - & - & - & - \\
\hline sasobica & - & - & - & - & - & - \\
\hline sastavina & parte componente o costitutiva & + & - & - & - & - \\
\hline sgodjaj & avvenimento; compiacimento & + & - & - & - & - \\
\hline složaj & combinazione & + & - & - & - & - \\
\hline sljednji & ultimo & - & - & - & - & - \\
\hline snemiliti se & non commiserare & + & - & - & - & - \\
\hline sobstvo & persona & + & - & - & - & - \\
\hline spojevina & - & - & - & - & - & - \\
\hline sporazumak & cointelligenza, accordo & + & - & - & - & - \\
\hline sporazumnik & - & - & - & - & - & - \\
\hline stanovit & fermo, costante, stabile & + & + & + & + & + \\
\hline sućutje & - & - & - & - & - & - \\
\hline sućutnik & nervo simpatico & - & - & - & - & - \\
\hline supor & - & + & - & - & - & - \\
\hline suprotak & - & - & - & - & - & - \\
\hline suprotivština & contrarietà, protervia & + & + & - & - & - \\
\hline suprotnik & - & + & - & - & - & - \\
\hline suvrst & specie omogenea & + & + & - & - & - \\
\hline svebiće & - & + & - & - & - & - \\
\hline svjestit & - & - & - & - & - & - \\
\hline svojiti & attribuire o ascrivere a sè & + & + & + & - & - \\
\hline svojtljivost & amore della parentela & - & - & - & - & - \\
\hline svrhunaravan & - & + & - & - & - & - \\
\hline šara & colore & + & + & + & + & + \\
\hline tjelesnoćutan & - & - & - & - & - & - \\
\hline trenovan & - & - & - & - & - & - \\
\hline tvor & opera; manifattura & + & - & - & - & - \\
\hline tvorilo & forma & + & + & + & + & + \\
\hline učin & $\begin{array}{l}\text { conseguenze d'un fatto } \\
\text { (criminoso) }\end{array}$ & + & + & - & - & - \\
\hline udobravanje & - & + & + & - & - & - \\
\hline udružba & - & - & - & - & - & - \\
\hline ujedinitba & - & - & - & - & - & - \\
\hline ujedinjenost & - & - & - & - & + & + \\
\hline umjera & equilibrio & + & - & - & - & - \\
\hline umotvor & prodotto d' arte (nobile) & + & - & + & + & + \\
\hline
\end{tabular}




\begin{tabular}{|c|c|c|c|c|c|c|}
\hline umotvorina & prodotto d' arte (nobile) & + & + & + & + & + \\
\hline umstveni & razionale & + & - & - & - & - \\
\hline upravljalo & - & - & - & - & - & - \\
\hline usilan & violento, forzoso & + & - & - & - & - \\
\hline usiljenost & affettazione & + & - & + & + & + \\
\hline usudan & - & + & - & - & - & + \\
\hline usudstvo & - & + & - & - & - & - \\
\hline usvjestan & me ne ricorderò bene (ta mi je č) & - & - & - & - & - \\
\hline utvora & $\begin{array}{l}\text { idea falsa, chimera; spettro, } \\
\text { fantasma }\end{array}$ & + & + & - & - & - \\
\hline utvoran & - & - & - & - & - & - \\
\hline uzajmica & - & + & - & - & + & + \\
\hline uzbiljina & - & - & - & - & - & - \\
\hline uzročenost & - & - & - & - & - & - \\
\hline uztrajnost & perseveranza & + & - & + & + & + \\
\hline vidok & vedetta; testimonio oculare & + & - & - & - & - \\
\hline vladohleplje & - & - & - & - & - & - \\
\hline vriednik & $\begin{array}{l}\text { uomo idoneo, abile; un } \\
\text { galantuomo }\end{array}$ & - & - & - & - & - \\
\hline vrjednoća & pregio; valore & + & + & + & + & + \\
\hline vrstnoća & valentia, bravura & + & + & + & + & + \\
\hline zadružnost & - & - & - & - & - & - \\
\hline zakonarstvo & legislazione & - & - & - & - & - \\
\hline zakonost & legalità; legittimità & + & - & - & - & - \\
\hline zarodak & embrione & + & - & - & - & - \\
\hline zasobica & donna rapita & + & + & - & - & - \\
\hline zasobični & - & - & - & - & - & - \\
\hline zasobni & consecutivo & - & - & - & - & - \\
\hline zločinica & - & + & - & - & - & - \\
\hline zločinstvo & azione cattiva, misfatto; delitto & + & + & + & + & + \\
\hline zlohotnost & malevolenza & + & - & - & - & - \\
\hline zlost & cattiveria, malignità & + & - & - & - & - \\
\hline značajnost & fermezza di carattere & + & - & + & + & + \\
\hline 200 & 108 & 109 & 38 & 37 & 38 & 46 \\
\hline
\end{tabular}

Kao što se vidi, najviše je navedenih Markovićevih riječi potvrđeno u Akademijinu i u Parčićevu rječniku, nešto manje od $55 \%$, dočim preostala četiri rječnika imaju ili malo manje od 20 \% (Broz-Iveković, Šonje i Anić) ili malo više od $20 \%$ (Jojić). 


\section{Tumačenje}

Ipak, treba pri tome, posebice kada je riječ o Parčićevu rječniku, biti na oprezu, jer premda neki Markovićevi primjeri nisu u njem izričito zapisani, nađu se kadšto riječi od kojih se one navedene lako mogu izvesti. U takvim bi se slučajevima moglo govoriti o »prikrivenoj « potvrđenosti. Primjerice, Marković ima glagolnu imenicu nasporivanje, od glagola nasporivati, koju ne nalazimo u Parčića (kao ni navedeni glagol), ali se zato u njegovu rječniku nahodi glagol nasporiti (accrescere, aumentare; render profittevole), ${ }^{13}$ od kojega je izveden (učestali) glagol nasporivati. Značenje glagola nasporiti (talijanski accrescere) valja razumjeti kao 'činiti da se štogod sporo troši (te stoga da bude izdašno, obilno)', pa otuda 'povećavati', 'umnožavati'. Parčić k tomu navodi i imenicu naspor [aumento, accrescimento; (gram.) rinforzamento]. ${ }^{14}$

Prema naspòriti birani bi ili uzorni lik toga učestaloga glagola bio nasporávati (a ne nasporívati), pa bi glagolna imenica glasila nasporávānje. Taj birani lik u svome prijevodu babilonskoga spjeva Enūma eliš, s akkadskoga izvornika, rabi i profesor Bulcsú László. Tako se, primjerice, za boga Marduka kaže da »razmještā p'aše i pojišta te nasporāvā st'aje« [posrijedi je Lászlóov zapis hrvatskoga naglaska dvonadslovnim sustavom s nenavodom (još se zove i dvoznaki prosti); u Vuk-Daničić-Budmani-Maretićevu petonadslovnome sustavu navodak bi izgledao ovako: »ràzmještā pâše i pòjišta tề naspòrāvā stàje«]. ${ }^{15}$ Štoviše, profesor László rabi i imenicu nasporitelj (»nasporitelj z'ēlja«, tj. »naspòritelj zêlja«) ${ }_{16}^{16}$ kojoj u bilješci značenje određuje ovako: »umnožitelj, pospješitelj’« (tj. "'umnòžitelj, pospjèšitelj'«). ${ }^{17}$

Slično bi se »prikrivena« potvrđenost mogla ustvrditi i za Markovićevu imenicu ujedinitba, koju Parčić ne navodi, ali ima ujedinba (unione, accordo), ${ }_{1}^{18}$ ili pak za glagolnu imenicu razglabanje, koju Parčić također ne navodi, ali ima glagol razglabati (commentare, discutere). ${ }^{19}$ A tako i za niz drugih primjera. Recimo, Marković ima pridjev dobrohotan, izvedenicu dobrohotnik, koja označuje nositelja takve osobine, te mislenu imenicu dobrohotnost. Parčić međutim navodi samo dobrohotan i dobrohotnost (benevolo i benevolenza), ali ima i glagol dobrohotjeti (voler bene, amare). ${ }^{20}$ Takvi bi i slični primjeri govorili u prilog

\footnotetext{
${ }^{13}$ Vidi Parčić, Vocabolario croato-italiano..., 483.

${ }^{14}$ Isto.

${ }^{15}$ László je prijevod prvi put objavio godine 1976. u Književnoj smotri, 8 (1976) 26-27, 5-20. Ovdje navodim prema knjizi: Bulcsú LÂSZLÓ, Hvalopj'ev S'ūncu, akkadski pjesmotvori u hrvatski pretočeni i komentarima popraćeni po Bulcsúu Lászlóu, (kao gost urednik) priredio i pogovor napisao Bojan Marotti, glavna urednica Zdravka Matišić, Zagreb, Odjel za orijentalistiku Hrvatskoga filološkog društva, 2012, 68 [Pl'očica šêstā, (tj. Plöčica šêstā), redak 124].

${ }^{16}$ Isto, 70 [Pl'očica s'edmā, (tj. Plöčica sëdmā), redak 2].

${ }^{17}$ Isto, bilj. uz redak 2.

${ }^{18}$ Vidi Parčić, Vocabolario croato-italiano..., 1055.

${ }^{19}$ Isto, 840.

${ }^{20}$ Isto, 103.
} 
tomu da je potvrđenost Markovićevih riječi u Parčićevu rječniku ipak nešto veća, recimo oko $60 \%$. A slično vrijedi i za Akademijin rječnik.

Pri određivanju potvrđenosti nisam uzimao u obzir razlike u pravopisu. Dakako, što se tiče Parčića, tu i nema razlika, jer i Marković i on, kao sljedbenici Zagrebačke filološke škole, pišu tvorbenim pravopisom (upravo »istim« pravopisom). To međutim nije slučaj s ostalim rječnicima. Tako primjerice Akademijin rječnik ima zapis $i z v r z ̌ b a$ za Markovićev lik $i z v r s ̌ b a,{ }^{21}$ ili pak zapis razvrzba za razvrstba, ${ }^{22}$ što sam prihvaćao kao potvrđene riječi. Zanimljivo je međutim da se u Akademijinu rječniku nalaze oba ova zapisa: i čimba i činba (potonji se upućuje na prethodni), ${ }^{23} \mathrm{tj}$. prvi prema izgovornome, a drugi prema tvorbenome pravopisu.

Osobit je primjer Markovićeva riječ prietvorba. I Parčićev i Akademijin rječnik imaju lik pretvorba (Parčić: transformazione; (teol.) transustanziazione), ${ }^{24}$ što nisam uzimao kao potvrđenu riječ. Drugo bi bilo da je posrijedi drugačiji zapis sljednika jata u dugome slogu, tj. prijetvorba, kako se i danas gdjekada piše. No riječ je zapravo o dvama različitim tvorbenim uzorcima, gdje se prema jednome od njih taj sljednik jata ne pokraćuje (prietvorba, dotično prijetvorba), a prema drugome se pokraćuje (pretvorba, dotično prjetvorba). Kada bismo taj dvoglas pisali jednim znakom posvuda gdje mu je po podrijetlu mjesto, recimo dvoslovom iẹ, kako je to katkada običavao činiti profesor László, mogli bismo obilježiti duljinu, a po potrebi i kračinu, na prvome dijelu dvoglasa, tj. priẹtvorba prema prị̂tvorba (poput, primjerice, grād 'naseljeno mjesto' prema grăd 'tuča'). Dosljedno lászlóovski, valja obilježiti i mjesto visine tona (László: napjevka) tzv. oviskom, pa bismo imali ovako: priẹtv'orba prema prǐetv'orba. No, strogo uzevši, znak za kračinu i nije potrebno pisati, jer je kračina obilježena upravo time što nije zapisana duljina (tzv. navod nenavodom). U tome pak slučaju dobivamo priẹtv'orba, što bi bio uzorni lik, naime lik koji pripada biranomu sustavu, te ujedno visokomu slogu jezika hrvatskoga (naglasak je dakle kratkouzlazni na dvoglasu).

Valja upozoriti na to da su neke od navedenih Markovićevih riječi potvrđene u pojedinim rječnicima, ali u drugačijem značenju (strogo bi se saussureovski reklo da je potvrđen samo označnik, signifiant, tj. lik riječi). Primjerice, za riječ sućutnik, koja u Markovića označuje osobu koja je sućutna, dakle nositelja takve osobine (kao što riječ dobrohotnik označuje onoga koji je dobrohotan),

\footnotetext{
${ }^{21}$ Vidi Rječnik hrvatskoga ili srpskoga jezika, na svijet izdaje Jugoslavenska akademija znanosti i umjetnosti, sv. IV, 367. Ondje se kaže ovako: "Načińeno u naše vrijeme od osnove glagola izvršiti nastavkom ba pred kojijem š glasi kao ž. «Pri tome se kao jedan od izvora navodi Sulekov njemačko-hrvatski rječnik, tj. riječ Ausführung (vidi Bogoslav ŠULEK, Deutsch-kroatisches Wörterbuch, sv. I-II, Agram, Verlag der Franz Suppan'schen Buchhandlung, 1860.). Ali dakako, u Šuleka piše izvršba (sv. I, 132). Taj je svezak Akademijina rječnika obrađivao Petar Budmani.

${ }^{22}$ Isto, sv. XIII, 776.

${ }^{23}$ Isto, sv. II, (redom) 25, 27.

${ }^{24}$ Vidi Parčić, Vocabolario croato-italiano..., 764.
} 
Parčić ima nervo simpatico (no za pridjev sućutan navodi talijanski compreso da simpatia, o da rammarico). ${ }^{25}$ Premda bismo očekivali da je u filozofskome nazivlju, u odnosu na opći jezik, značenje suženo, »specificirano«, ovdje zapravo imamo obrnut slučaj.

Katkada opet nije posrijedi suženo, nego posve drugo značenje. Tako za imenicu zasobica (obično: vremena zasobica), koja u Markovića znači 'susljednost', 'sukcesija', te tvori pojmovni par s imenicom sasobica (obično: vremena sasobica), koja pak znači 'istodobnost', 'koegzistencija,', ${ }^{26}$ Parčić ima donna rapita (condotta a cavallo col rapitore), tj. 'oteta žena', premda za pridjev zasobni navodi consecutivo. ${ }^{27}$ I Akademijin rječnik za riječ zasobica kaže »oteta djevojka ${ }^{28}$ te donosi više potvrda iz narodnih pjesama, a tako ima i Broz-Ivekovićev rječnik, gdje se kaže ovako: ${ }^{29}$ "ugrabljena, oteta djevojka, koju otimač baci za se na konja, pa je onako za sobom nosi«. Markovićevu riječ zasobica, kao i njezino značenje, valja međutim izvoditi iz Stullijeva Rjecsoslòxja (1806.), gdje se nalaze riječi, upravo prilozi, zasob i zasobice, ${ }^{30}$ za koje pak Stulli donosi najprije talijansku, pa potom i latinsku otpovjednicu, tj. continuo i continuus, a zatim navodi i primjer: »tridni zazob [tj. zasob], tridni zasobice, tre giorni di seguito, triduo perpetuo«, dakle 'tri dana u slijedu', 'tri dana bez prijekida', 'tri dana u kontinuitetu'.

Slično je i s Markovićevim riječima medjusobica i uzajmica, koje obje znače 'odnos', 'relacija'. Imenicu medjusobica nemaju ni Parčić, ni Akademijin rječnik, ni Broz-Iveković, ni Šonje, ali ju navodi Anić, i to u zapisu međùsobica, i s takvim naglaskom, te kaže ovako: »Ono što tinja kao pritajen sukob ili neraščišćen račun između dvije ili više osoba i strana; razmirica, račun koji tko ima s kim; spor, raspra. ${ }^{31}$ Riječ se nalazi i u Velikome rječniku hrvatskoga standardnog jezika, kojemu je glavna urednica Ljiljana Jojić (a koja je priredila i spomenuti Anićev rječnik), gdje se dopušta i naglasak mëđusobica (uz međùsobica), te se veli »razmirica «. ${ }^{32}$ Za riječ pak uzajmica Anić kaže »pozajmica, zajam «, ${ }^{33}$

\footnotetext{
${ }^{25}$ Isto, 967.

${ }^{26}$ Usp. sljedeću rečenicu iz Markovićeve Etike (114): »Da uzmogne mišljenje (sudjenje) postati istinito, da uzmognu u našoj sviesti pretegnuti istinite sveze medju pojmovi, tomu je potrebita hotimična pozornost na sadržaje pojmova, tomu je potrebno, da u sviesti prevladaju sadržajne razložne sveze nad svezami pukimi mehaničnimi t. j. nad svezami po pukoj vremenoj sasobici ili zasobici.«

${ }^{27}$ Vidi Parčić, Vocabolario croato-italiano..., 1163.

${ }^{28}$ Vidi Rječnik hrvatskoga ili srpskoga jezika, na svijet izdaje Jugoslavenska akademija znanosti i umjetnosti, sv. XXII, 407.

${ }^{29}$ Vidi Broz-Iveković, Rječnik hrvatskoga jezika, sv. II, 814.

${ }^{30}$ Vidi Joakim STULLI, Rjecsoslòxje u komu donosuse upotrebljenia, urednia, mucsnia istieh jezika krasnoslovja nacsini, izgovaranja i prorjecsja, Dubrovnik, Po Antunu Martekini, 1806, sv. 2, 634 .

${ }^{31}$ Vidi Anić, Veliki rječnik hrvatskoga jezika..., 740.

${ }^{32}$ Vidi Jojić (gl. ur.), Veliki rječnik hrvatskoga standardnog jezika..., 721.

${ }^{33}$ Vidi Anić, Veliki rječnik hrvatskoga jezika..., 1702.
} 
a Ljiljana Jojić »zajam «. ${ }^{34}$ Tu riječ nemaju ni Parčić, ni Broz-Iveković, ni Šonje, ali je bilježi Akademijin rječnik, gdje se međutim kaže ovako: $:^{35}$ »uzajaman, $z a-$ jednički rad, kojim se pomažu dvije strane ili više ńih«.

Kadšto pak valja biti oprezan, jer neke posve uobičajene riječi u Markovića ne znače ono na što smo danas (uglavnom) navikli. Primjerice, imenica pore$z n i k$ ne znači 'službenik koji utjeruje porez', pa ni 'službenik koji u poreznom uredu razrezuje i obračunava porez', kako navodi Šonje, ${ }^{36}$ nego 'porezni obveznik'. Pridjev stanovit ne znači 'neki', nego 'stalan', 'pouzdan' (fermo, costante, stabile, kako kaže Parčić). ${ }^{37}$ Mislena imenica značajnost ne znači 'važnost', nego ono što Parčić na talijanski prevodi kao fermezza di carattere..$^{38} \mathrm{~A}$ ni mislena imenica usiljenost ne znači 'neprirodnost', nego 'prisiljenost'. Pače i Parčić kaže affettazione, premda ima pridjev usilan, koji prevodi na talijanski kao violento, forzoso. ${ }^{39}$ Nadalje, sastavina znači 'sastavni dio čega', a ne možda 'složaj', šara znači 'boja', ili 'krasa', kako još ima Parčić, ${ }^{40}$ a ne 'ukrasni crtež u boji ili u više boja utkan, upleten ili izvezen na tkanini ili pletivu ili urezan na tvrdoj podlozi', kako nalazimo u Šonje. ${ }^{41}$ Od dviju talijanskih riječi kojima Parčić prevodi imenicu goj, tj. tranquillità i educazione, Marković tu imenicu redovito rabi u značenju talijanske riječi educazione.

Napokon, valja upozoriti i na nekoliko manje poznatih riječi. To se, prije svega, odnosi na imenicu pra, koja je neobično važna za Markovićevu Etiku (a jednako je tako bitna i za Markovićevu etiku). Ta je imenica potvrđena u Parčićevu rječniku (causa contenziosa, lite), ${ }^{42}$ te također u Akademijinu rječniku, gdje se kaže »raspra, parba, pravda, tužba, svađa«. ${ }^{43}$ Imenica pra, ruski nря, u vezi je s glagolom preti (se). Posrijedi je praslovjenski korijen "pbr-, od kojega se u nas javlja više osnova: pr- (npr. pra), par- (npr. parba), pir- [npr. pre-pir-ati (se)], por- (npr. prije-por). Takvih je jednosložnih imenica ženskoga roda tzv. $e$-sklonidbe (žèna, žènē) u nas razmjerno malo. Primjerice, osim imenice pra, u knjizi Naglasni sustav standardnoga hrvatskog jezika Bratoljub Klaić navodi još ove: ckä ('daska'), kljä (vrsta snijeti na žitu), knä (vrsta crvene boje) i tmä ('tama'). ${ }^{44}$ Budući da se imenica pra rijetko rabi, navodim ovdje cijelu sklonidbu:

\footnotetext{
${ }^{34}$ Vidi Jojić (gl. ur.), Veliki rječnik hrvatskoga standardnog jezika..., 1652.

${ }^{35}$ Vidi Rječnik hrvatskoga ili srpskoga jezika, na svijet izdaje Jugoslavenska akademija znanosti i umjetnosti, sv. XX, 235.

${ }^{36}$ Vidi Šonje (gl. ur.), Rječnik hrvatskoga jezika..., 891.

${ }^{37}$ Vidi Parčić, Vocabolario croato-italiano..., 953. Parčić pridjev stanovit upućuje na stanovan, pa navodim talijanske otpovjednice toga pridjeva (952).

${ }^{38}$ Isto, 1182.

${ }^{39}$ Isto, 1074 .

${ }^{40}$ Isto, 359.

${ }^{41}$ Vidi Šonje (gl. ur.), Rječnik hrvatskoga jezika..., 1215.

${ }^{42}$ Vidi Parčić, Vocabolario croato-italiano..., 735.

${ }^{43}$ Vidi Rječnik hrvatskoga ili srpskoga jezika, na svijet izdaje Jugoslavenska akademija znanosti i umjetnosti, sv. XI, 351.

${ }^{44}$ Vidi Bratoljub KLAIĆ, Naglasni sustav standardnoga hrvatskog jezika, izvorni rukopis uredio Božidar Smiljanić, Zagreb, Nova knjiga Rast, 2013, 92.
} 


$\begin{array}{lll} & \text { Jednina } & \text { Množina } \\ \text { N. } & \text { prä } & \text { prë } \\ \text { G. } & \text { prề } & \text { párā } \\ \text { D. } & \text { prï } & \text { präma } \\ \text { A. } & \text { prü } & \text { prë } \\ \text { V. } & \text { prö } & \text { prë } \\ \text { L. } & (\text { o }) \text { prï } & (\text { o) präma } \\ \text { I. } & (s) \text { prôm } & (s) \text { präma }\end{array}$

Marković ne bilježi naglasak u nominativu jednine, tj. prä, ali ga bilježi jedanput u genitivu jednine, i to kao prë (»Peti nasuprot kažu, da pràvo niče iz prikornosti borbe i prë, ter pravo nastaje tek sporazumkom, koji izmiruje i UKLANJA PRU.«). ${ }^{45}$ To je zacijelo (nehotičan) propust, jer se u genitivu jednine očekuje dugosilazni naglasak (kao u čakavskome dvonaglasju vodä, vodê, gdje je vodê postalo od vodẽ). ${ }^{46}$

Manje je uobičajena i imenica vidok, tvorena kao svjedok, dometkom -ok, istoga naglasnoga uzorka, tj. vidok, vidòka, a i sličnoga značenja, tj. 'onaj koji je nešto vidio', 'onaj koji je bio svjedokom čega'. Potvrđena je u Parčića (soprantendente; vedetta; testimonio oculare $)^{47}$ i u Akademijinu rječniku, gdje se navode ova tri značenja: 'nadglednik', 'očevidac' i 'vidik'.48

Još su dvije imenice zanimljive: zločinica i tvor. Prva ne toliko zbog značenja, jer je značenje razvidno, nego više zbog neobične (mocijske) tvorbe, budući da je u nas uobičajeno zločinka, kako uglavnom navode rječnici (od navedenih, zločinica je potvrđena samo u Akademijinu rječniku). ${ }^{49}$ Međutim, ima slično tvorenih primjera, recimo lakomica prema lakomac, šaljivica prema šaljivac. ${ }^{50}$

Što se pak tiče imenice $t v o r$, uglavnom se navodi životinja, a znatno rjeđe $t v o r$ prema glagolu tvoriti, onako kako značenje opisuje Akademijin rječnik: »Ono, što je radom ostvareno, stvoreno, učińeno; posljedak ili rezultat stvaralačkog rada, djelo, a gdjekada i sama radńa. ${ }^{51}$ Ipak, da te dvije imenice nisu u pravome smislu istozvučnice, pokazuje razlika u naglasku: životinja će biti tvör, tvòra, a riječ koja znači 'djelo' - tvôr, tvöra. Potonji se naglasak može potvrditi u predgovoru već spomenutoga prijevoda babilonskoga spjeva Enūma eliš, gdje profesor László, zahvaljući se na pomoći Erici Reiner, profesorici na Istočnjačkome

\footnotetext{
${ }^{45}$ Vidi Marković, Etika..., 178.

${ }^{46} \mathrm{U}$ navedenome izdanju nisam na to posebno upozorio. Moguće je da je Markovića »povukao« naglasak iz nominativa jednine.

${ }^{47}$ Vidi Parčić, Vocabolario croato-italiano..., 1107.

${ }^{48}$ Vidi Rječnik hrvatskoga ili srpskoga jezika, na svijet izdaje Jugoslavenska akademija znanosti i umjetnosti, sv. XX, 836-837.

${ }^{49}$ Isto, sv. XXII, 937.

${ }^{50}$ Obje se riječi, i lakomica i šaljivica, navode primjerice u Šonjinu rječniku [(redom) 529, 1214].

${ }^{51}$ Vidi Rječnik hrvatskoga ili srpskoga jezika, na svijet izdaje Jugoslavenska akademija znanosti i umjetnosti, sv. XIX, 28.
} 
zavodu Sveučilišta u Chicagu (Oriental Institute of the University of Chicago), na jednome mjestu kaže da mu je pomagala »'i_tvorom«, tj. »ì_tvorom «. ${ }^{52} \mathrm{Tu}$ se vidi da naglasak skače na prednaglasnicu, pa je dakle posrijedi, Lászlóovim nazivljem rečeno, »kratka bezvisica«. ${ }^{53}$

\section{Zaključak}

Tako nam jedan nevelik uzorak, svega dvjesto riječi uzetih iz Markovićeve Etike, od kojih većina pripada filozofskomu ili pak, općenitije rečeno, znanstvenomu nazivlju, ali ima i primjera koji su dio općega jezika, istodobno pokazuje i Markovićevu skrb za (filozofsko) nazivlje, ali ujedno i stanje u kojem se danas nalazi hrvatski (književni) jezik. To posebice vrijedi za rječnike »suvremenoga (književnoga) jezika, gdje se može potvrditi jedva kakvih dvadesetak posto navedenih riječi. Taj bi postotak zacijelo bio još porazniji da se sličnoj razglobi podvrgne golema Markovićeva Logika. Istom je s toga motrišta, tj. kada se ta činjenica u potpunosti osvijesti, moguće doista razumjeti ono na što je prije kakvih dvadeset i pet godina upozorio profesor László:

»Kada bismo se zarekli da svakim težatnim danom usvojimo po jednu novu rieč, za pedeset bismo godina ovladali istom petnaestima tisućama rieči. To je 10 posto popisanih rieči ili svaka deseta. A kako znamo, polovica naših rieči nije popisana, onda je to 5 posto ili svaka dvadeseta. ${ }^{54}$

Osobito je zanimljivo da tu skrb za (filozofsko) nazivlje sam Marković ne shvaća kao neki prinos »čistunstvu« ili kao pokušaj da se (hrvatska) filozofija zatvori u uske hrvatske granice, nego upravo obrnuto, kao temeljni uvjet da se dohvati njezin »svesvjetski vidokrug«. Evo kako to obrazlaže u svojoj rukopisnoj Logici:

»Kosmopolitski biljeg filosofije udešava nam priliku da se ne podjarmimo pod koji inonarodni smjer filosofijski, recimo pod njemački, nego da baš u filosofiji obćenitoj svjetskoj nadjemo uztuk proti premoći germanskoga duha u nas. Da se je prosvjeti našoj pridići samo na njemačkoj, mi izgibosmo u pukom nasljedovanju, i klica samorodna, samosvojna u nas usahnu. Ali su nam tuj takodjer Inglezi i Francezi, Talijani i sjeverni Slaveni, pa dakako prije svih i stari Heleni,

\footnotetext{
${ }^{52}$ Vidi László, Hvalopj'ev S'ūncu, 30.

${ }^{53} \mathrm{O}$ »kratkim bezvisicama«, ili o »kratkim bezvisnim osnovama«vidi Bulcsú LÁSZLÓ, Bilježka o_književnōme naglasku hrvātskōme, Suvremena lingvistika, 22 (1996) 41-42, 333-391, posebice 351-352.

${ }^{54}$ Vidi Bulcsú LÁSZLÓ, Svaka dvadeseta rieč hrvatskoga jezika nije popisana!, Globus, 4. veljače 1994., 40. Svi su članci što ih je profesor László sredinom devedesetih godina prošloga stoljeća objavio u Globusu, imali urednički naslov. Ovdje je posrijedi propust, jer naslov bi zapravo trebao glasiti: Samo je svaka dvadeseta rieč hrvatskoga jezika popisana! Dakle ne da svaka dvadeseta nije popisana, nego samo svaka dvadeseta jest popisana.
} 
u kojih nam je crpsti okrepne piće ${ }^{55}$ na putu za istinom, dobrotom i ljepotom. I upravo ovo je znamen i vriednost našega nastojanja oko znanosti na našem narodnom jeziku, da nam je tim dozvoljen i baš otvoren potrebni svesvjetski vidokrug, da nam je možno obazirati se u znanosti našoj na romanske narode, na Ingleze, na Slavene sjeverne, dok se dio Niemaca u filosofijskih predavanjih svojih premalo osvrću na druge sadanje narode, i prikazuje stvar tako, kao da ne treba ni znati za sadanje francezke i englezke filosofe. [...] I do ničesa nam ne budi toliko stalo, ništa ne držimo životnijim pitanjem našega znanstvenoga napredka, kako samostalnu porabu djelâ i onih drugih naroda pored Njemaca. $\ll^{56}$

Dakako, u vrijeme kada piše Marković na pameti ima »germanski duh«, te ustaje protiv njegova utjecaja. No koliko su te riječi zadržale svoju svježinu, svoju iznimnu važnost sve do dana današnjega, moguće je pokazati jednim posve jednostavnim »pokusom«. Recimo da u prvim dvjema rečenicama pridjeve njemački i germanski zamijenimo pridjevom anglosaksonski, te pročitamo potom te dvije »nove« rečenice. Evo kako bi one glasile:

»Kosmopolitski biljeg filosofije udešava nam priliku da se ne podjarmimo pod koji inonarodni smjer filosofijski, recimo pod anglosaksonski, nego da baš u filosofiji obćenitoj svjetskoj nadjemo uztuk proti premoći anglosaksonskoga duha u nas. Da se je prosvjeti našoj pridići samo na anglosaksonskoj, mi izgibosmo u pukom nasljedovanju i klica samorodna, samosvojna u nas usahnu.«

Taj nam preinačeni navodak, kao u kakvu zrcalu, pokazuje dokle smo stigli i gdje se nalazimo danas, nešto više od 125 godina nakon uvedbe Brozova pravopisa. I upravo je to razlog zašto je bilo važno objaviti Markovićevu rukopisnu Etiku. Ali dakako, to nije dovoljno, jer bi kritički trebalo objaviti cjelokupnu ostavštinu Franje pl. Markovića (ili makar što veći njezin dio). Ne samo zato da bi Markovićeva misao, misao dakle jednoga od najvažnijih hrvatskih filozofa otkada se u Hrvatskoj filozofira na hrvatskome jeziku, bila dostupna, nego i zato da se omogući uvid u silno bogatstvo filozofskoga nazivlja koje nam u svojim djelima nudi Marković. Jer, premda donekle protusmisleno, moglo bi se ustvrditi sljedeće: Marković je utemeljitelj hrvatskoga filozofskoga nazivlja; jedina je nezgoda u tome što ono, svojom glavninom, nije (bilo) prihvaćeno, pa nije ni moglo postati dijelom hrvatske filozofije.

\footnotetext{
${ }^{55}$ Riječ pïća znači 'hrana', a u vezi je s glagolom pïtati 'hraniti' (od čega je pridjev, a zapravo trpni particip prezenta pïtom, kojemu bi temeljno značenje prema tome bilo 'uhranjen'). Parčić, među ostalim, veli cibo, alimento (Vocabolario croato-italiano..., 638), dočim se u BrozIvekovićevu rječniku, gdje je obilježen naglasak pïća, kaže ovako: »hrana, osobito za stoku (n. p. sijeno, slama itd.)« (sv. II, 30).

${ }^{56}$ Vidi Franjo MARKOVIĆ, Logika, rukopis se čuva u Arhivu Hrvatske akademije znanosti i umjetnosti u Zagrebu pod oznakom XV 37. Navodim prema primjerku 2a, 6. Vidi o tome Marotti, O Markovićevim filozofskim rukopisima u arhivima HAZU, 121-124 (poglavlje O načelima priređivanja). Usp. i Marković, Logika, priredio Srećko Kovač, Prilozi za istraživanje hrvatske filozofske baštine, 250 (uz nekoliko neznatnih razlika). Iz ovoga je malo duljega ulomka uzet i motto za ovaj članak.
} 


\section{Bojan Marotti* \\ Terminology in Markovićs Ethics}

Summary

Croatian philosopher, writer, and theatre and literary critic, the noble Franjo Marković (1845-1914), the first professor of philosophy at the restored University of Zagreb (1874), was born in Križevci, a small town in north-western Croatia. He attended the gymnasium at the Nobility Boarding School in Zagreb (1854-1862), and then studied Classics, Slavic studies, and philosophy in Vienna (1862-1865). He graduated in 1865, and the next year he passed his gymnasium professorship exam. He worked as an assistant at gymnasia in Osijek and Zagreb. In 1870, after one political protest, he left his service and went to Vienna for further study of philosophy, where he bacame a student of Herbart's follower Robert Zimmermann, receiving his $\mathrm{PhD}$ in philosophy in 1872. He returned to Zagreb, becoming editor of Vienac (1872-1873). In 1874 he was appointed as the first head of the Department for philosophy and the dean of the Faculty of Philosophy in Zagreb. He became a member of the Academy in 1876, and then rector of the University in the academic year 1881/1882. He continued to teach until his retirement in 1909.

The Archives of the Croatian Academy of Sciences and Arts, as well as the Archives of the Department for the History of Croatian Literature at the Institute for History of the Croatian Literature, Theatre, and Music (which is also part of the Croatian Academy of Sciences and Arts) preserve Marković's rich manuscript heritage. This heritage contains primarily philosophical manuscripts. They are to a large extent related to lectures (or preparations for lectures) at various stages of completeness, which Marković held to his students at the University until he retired in 1909 and also on later occasions, so to say, until he died. Those manuscripts refer to different sections of philosophy because Marković taught almost all segments of philosophy, from logics to aesthetics, as well as some sciences that are no longer regarded as parts of philosophy, for example psychology and pedagogy.

As the first professor of philosophy with a systematic teaching record, translating and writing in Croatian language (and not Latin, Italian, Hungarian or German), Marković made a substantial impact on the development of Croatian philosophical terminology, because in his philosophy, as it could be seen in manuscripts, Marković paid a great attention to the terminology in general, and especially to the philosophical terminology.

In this paper, his concern for (philosophical) terminology is demonstrated by the example of his Ethics. From this work, two hundred words have been

\footnotetext{
* Bojan Marotti, PhD, Institute for the History and Philosophy of Science, Croatian Academy of Sciences and Arts, Zagreb; Address: Ante Kovačića 5, HR-10000 Zagreb, Croatia; E-mail: bojan.marotti@zg.t-com.hr.
} 
chosen, most of which can be considered philosophical or, broadly speaking, scientific terms, but some of them also belong to the general (or every day) language. To determine how many of these words have been verified in the Croatian language, six Croatian dictionaries were selected, as follows: Dragutin Parčić, Vocabolario croato-italiano (1901), Dictionary of the Croatian Academy of Sciences and Arts (1880-1976), Ivan Broz and Franjo Iveković, Rječnik hrvatskoga jezika (1901), Jure Šonje (ed. in chief), Rječnik hrvatskoga jezika (2000), Vladimir Anić, Veliki rječnik hrvatskoga jezika (2004), and Ljiljana Jojić (ed. in chief), Veliki rječnik hrvatskoga standardnog jezika (2015). After comparing and analyzing, the conclusion was made that the most Markovićs words have been verified in the Dictionary of the Croatian Academy, as well as in the Parčićs Croatian-Italian Dictionary, somewhat less than 55\%, while the remaining four dictionaries contain either less than 20\% (Broz-Iveković, Šonje and Anić) or slightly over 20\% (Jojić). These numbers show Markovićs concern for (philosophical) terminology, but, at the same time, they also point to the current state of Croatian (literary) language. And this is especially true if we look at the dictionaries of (Croatian) »contemporary« language, where barely twenty percent of Marković's words can be verified.

Marković is usually understood as an aesthetician, and also as a follower of Johann Friedrich Herbart, but both are doubtful due to the fact that we know very little about Marković's philosophy as a whole, better to say, we know only some chapters of that whole. Therefore, at the end of the paper, it is proposed that all Marković's manuscripts should be published, so that the thought of one of the most important Croatian philosophers could finally be researched in its wholeness.

Key words: Franjo Marković, ethics, (philosophical) terminology, Croatian philosophy, Croatian lexicography, history of the Croatian language, Croatian Literary Language. 